\title{
Accounting
}

\section{Profitability variations and disparity in automobile sector: A case of leading Indian Automobile companies}

\author{
Anis Ali ${ }^{*}$
}

${ }^{a}$ College of Business Administration, Prince Sattam Bin Abdulaziz University, Al kharj- 11942, Saudi Arabia

\section{A B S T R A C T}

The Indian automobile sector is the biggest market and emerging by displacing some advanced countries. The Indian automobile sector contributes positively and progressively to the growth and development of the Indian economy. The study is based on secondary data and considers the financial statements available on concerned websites. Ratio analysis, ANOVA (Analysis of Variance), CV (Coefficient of Variation), and rank correlation applied to analyze the data extracted from the financial statements of leading Indian automobile companies. The study reveals that there is a significant difference in the profitability of the Leading Indian automobile companies for the period 2011 to 2020. There is a moderate positive relational relationship between PBDIT(Profit Before Depreciation, Interest, and Tax) ratio and PBIT(Profit Before Interest and Tax) ratio and their variability while PBT ( Profit Before Tax) ratio and PAT ( Profit After Tax) ratio and their variability positively and highly correlated. This reveals that manufacturing expenses and depreciation do not affect profitability while profitability governs the interest and taxes of the leading Indian automobile companies. The study suggests a possible reduction in all direct and indirect costs, optimum cost of capital, or low cost of capital structure can be considered to avoid excessive burden against the profits of the negative performing leading Indian automobile sector companies.

\section{Introduction}

The Indian automobile sector is the fourth largest market displacing Germany in selling passenger and commercial vehicles and is expected to achieve third position replacing Japan by 2021. Indian automobile market very strong in terms of exports of automobile products and fulfill the domestic demand. Indian automobile market can be bifurcated into four categories i.e. twowheelers, three-wheelers, passenger vehicles, and commercial vehicles. In each automobile category, few companies manufacturing and fulfilling domestic and export demand of the vehicles. In the financial year 2020, Indian automobile exported 4.77 million with a compound annual growth rate of $6.94 \%$. The Indian automobile industry is a growing industry and expected to achieve USD 251-282 billion by 2026 (IBEF). The operational profitability of a business organization reflects the profitearning capacity from the business activities of the organization. The systematic and individual analysis of all the cost ingredients of the product discloses the pattern of cost composition and indicates the efficiency and inefficiency of the business organization. Normally, there are three types of overhead in any manufacturing organization i.e. manufacturing, selling and distribution, and administrative and management expenses, etc. The comparative analysis of the manufacturing expenses explains the cost efficiency and manufacturing velocity of the business organization. The comparative analysis of selling and distribution, and administrative and management expenses reveal the marketing efficiency and managerial efficiency of the business organization. Overall, manufacturing efficiency, selling distribution efficiency, and administrative efficiency reelect the operational profitability of the business organization, alternatively. In the last decade, there is fluctuations and disparity in operational efficiency i.e. manufacturing, selling and distribution, and administrative efficiencies among the leading automobile

* Corresponding author

E-mail address: ah.ali@psau.edu.sa (A. Ali) 
sector companies in India. There is a lack of study regarding the comparative profitability of the Indian automobile sector companies and components behind the disparity of operational profitability. The study aims to find out the disparity among the profitability of the Indian automobile sector companies and recognize the factor responsible for the disparity in profitability ratios or detect the responsible factors in low-performing businesses.

\section{Literature Review}

Kumar and Kaur (2016) studied the profitability and size relationship between Indian automobile companies for the period 1998 to 2014 and found a mixed relationship between the size and profitability of the automobile companies. Kaur and Kaur (2016) attempted to ascertain the profitability of the Indian automobile companies from the various segments listed in Bombay stock exchange from 2003-04 to 2013-14 and found that the profitability of Indian automobile sector companies governed by the liquidity, growth of the firm manufacturing velocity, operational efficiency, payment to creditors and proprietary position. Attari and Raza (2012) found that the length of the Cash Conversion Cycle (CCC) and return on the owners" fund negatively related to the profit-earning capacity in the automobile companies. Jaisinghani and Tandon (2016) studied the 105 automobile Indian firms for the period 2004 to 2013 and found a positive relationship between profitability and research and development. The relationship between profitability and research and development is U-shaped due to excess spending. They suggested investments in Research and development activities at an optimum level. Arumugam et al. (2016) advocated the importance of the automobile sector for the growth of the economy. They studied the profitability of the Indian automobile sector and found that the profitability of the Indian automobile companies effected by the operating ratio up to a larger extent. Ashraf (2012) found the negativity between the components of the working capital management and profitability while positivity between the size of the firm and the profitability in the companies from the various sector. Gopalakrishnan (2014) studied the growth of the Indian automobile sector companies and found the negative trend in the working capital and suggested the expansion in the rage of the products, appropriate marketing strategy, and cost reduction and revision of the sale prices of the products to enhance the turnover and profit, ultimately. Paliwal and Chouhan (2017) studied the profitability and the liquidity of the automobile industry and found the positivity between the profitability and liquidity and suggested the trade-off between the liquidity and profitability. Shajar (2017) study the automobile sector firms and found that the components of the working capital and cash conversion cycle hurt the profitability measured in the context of the assets. He suggested that the management of the working capital components will enhance the profitability of the companies. Simlai and Guha (2019) explored that the debt-equity ratio of the Indian automobile companies is not 2:1 as per the standard and Indian automobile companies manage the fund from their sources. The gross profitability and operating profit ratio of the Indian automobile companies are satisfactory except Tata motors Ltd. Hassan and Shrivastava (2019) studied the working capital and profitability of the Tata Motors Ltd for the period 2013 to 2017 and found the significant relationship between the components of working capital and the profitability. Gandhi (2017) stated that the Indian automobile industry is the developing sector in the Indian economy. Gandhi selected the Tata Motors Ltd. and Mahindra and Mahindra Ltd. for the period 2005-60 to 2014-15 and found the difference between the profitability of the Tata Motors Ltd and Mahindra and Mahindra Ltd. Suresh and Sengottaiyan (2015) studied the relationship of capital structure and the profitability and found the mixed relationship i.e., positive and negative relationship between the capital structure and profitability of the Indian automobile companies. Jamali and Asadi (2012) explored the relationship between the profitability and the managerial efficiency of the Indian automobile companies and found strong positivity and suggested the enhancements of the management efficiency to improve the profitability. Singh et al. (2020) explored that the Indian automobile is the most progressive industry in the Indian market with and growth rate of $7.64 \%$ per annum. New entrants in the Indian automobile sector enhance the competition. So, there is a need to understand the needs and requirements of the Indian customers to survive in the tough competition in the market and enhance profit and profitability. Tripathi and Talukder (2020) studied the supply chain performance and profitability of the Indian automobile sector and found that the profitability is affected by the poor distribution of the products more than the operational velocity and the utilization of the resources. Swalih et al. (2021) studied the financial soundness of the Indian automobile sector and explored that the Indian automobile companies will be able to pay out their debts smoothly in near future. Tripathi and Rao (2016) found the growth trend in the turnover of two-wheeler and passenger vehicle in the Indian automobile industry. Hiran (2016) found negativity between the inventory turnover ratio and operating profit while the quick ratio is positively correlated with the operating profit and net profit. The current ratio of the companies has a negative relationship with the profit in Indian automobile companies. They further explored that the financial leverage and operating leverage of the automobile companies negatively correlated with profitability. Kumar and Choudhary (2019) studied the Indian automobile sector and explored that governments' policy of taxation, investment, and industrial policy affects the performance of automobile companies. Ranjithkumar and Eahambaram (2018) study the automobile sector companies listed in Bombay stock exchange for the period 2013-14 to 2017-18 and found that the Indian automobile sectors' performances governed by the liquidity position and growth of the firms, velocity of operational activities, and payment strategies and policies.

\section{Hypotheses}

$\mathrm{H}_{01}$ : There is no difference between the average PBDIT ratios of leading Indian automobile companies. 
$\mathrm{H}_{02}$ : There is no difference between the average PBIT ratios of leading Indian automobile companies.

$\mathrm{H}_{03}$ : There is no difference between the average PBT ratios of leading Indian automobile companies.

$\mathrm{H}_{04}$ : There is no difference between the average PAT ratios of leading Indian automobile companies.

\section{Research Methodology}

The study is purely based on the secondary data extracted from the financial statements of the leading Indian automobile sector companies for the period 2011 to 2020. Tata Motors Ltd. (Tata), Maruti Suzuki India Ltd. (Maruti), Mahindra and Mahindra Ltd. (Mahindra), Hero Motocorp Ltd. (Hero), Bajaj Auto Ltd. (Bajaj), Ashok Leyland Ltd. (Ashok0, TVS Motor Company Ltd. (TVS), and Eicher Motors Ltd. (Eicher) companies selected for the study operational profitability disparity. ANOVA (Analysis of Variance) and CV (Coefficient of Variations) of operational profitability ratios of automobile companies calculated to know the disparity and variability of operational profitability (Ali, 2020).

$\mathrm{F}=\frac{B s s / d f 1}{W s s / d f 2} ;$ While, $\mathrm{F} \geq \mathrm{F} \propto$, Reject $\mathrm{H} 0$

where, F= Fishers' Ratio, Bss/df1 = sum of squares between samples divided by respective degrees of freedom, Wss/df2 $=$ sum of squares within samples divided by respective degrees of freedom, and $\mathrm{F} \propto=$ critical value.

Co-efficient of Variation $(\mathrm{CV})=\frac{\text { Mean }}{\text { Standard Deviation }}$

where,

\begin{tabular}{lllll}
\hline CV & CV $<0.10$ & $0.10 \leq \mathrm{CV} \leq 0.20$ & $0.20 \leq \mathrm{CV} \leq 0.30$ & CV $>0.30$ \\
\hline Interpretation & Very good & Good & Acceptable & Not Acceptable \\
\hline
\end{tabular}

Spearman's rank correlation calculated to know the relational correlation between the variables.

Spearman's Rank correlation $\left(\mathrm{r}_{\mathrm{s}}\right)=1-\frac{6 \sum(D * D)}{n(n * n-1)}$

\section{Analysis}

The analysis of the study can be divided among the four categories to get the disparity of operational profitability and cost components responsible for low operational profitability and disparity of operational profitability among the automobile sector companies of India.

I. $\quad$ PBDIT (Profit before Interest, Depreciation, and Tax) disparity and variability

II. $\quad$ PBIT (Profit Before Interest, and Tax) disparity and variability

III. $\quad$ PBT (Profit Before Tax) disparity and variability

IV. PAT (Profit After Tax) disparity and Variability

\subsection{PBDIT (Profit before Depreciation, Interest, and Tax) disparity and variability}

PBDIT (Profit before Interest, Depreciation, and Tax) is the absolute amount obtained deducting all the direct and indirect manufacturing cost from the revenue or excess of revenue over the all direct and indirect manufacturing cost is called PBDIT.

PBDIT Ratio $=\frac{\text { PBIDT }}{\text { Revenue }} 100$

where, PBDIT = Revenue - Direct and Indirect manufacturing cost,

The higher PBDIT ratio reflects the manufacturing efficiency and cost control over the direct and indirect cost of manufacturing of the business organization.

Table 1

ANOVA of PBDIT ratio of Indian leading automobile companies

\begin{tabular}{llrlllr}
\hline \multicolumn{1}{c}{ Source of Variation } & SS & $d f$ & $M S$ & $F$ & $P$-value & F crit \\
\hline Between Groups & 4177.795 & 7 & 596.8278 & 60.17288 & $1.48 \mathrm{E}-27$ \\
Within Groups & 714.1357 & 72 & 9.918552 & & \\
\hline Total & 4891.931 & 79 & & & \\
\hline
\end{tabular}

Source: Calculation based on ratios given in appendix 1.

Based on the results of Table 1, hypothesis $\mathrm{H} 01$ is rejected as the calculated value of the F ratio (60.17288) is more than the critical value of the F ratio (2.13965551). Hence, there is a significant difference among the average PBDIT profitability of the leading Indian automobile companies. The comparative average PBDIT ratio and variability explain the average PBDIT and its comparative variability trend. 
Table 2

Relational Co-variability of average PBDIT ratio and variability of PBDIT ratio of leading Indian automobile companies (2011 to 2020)

\begin{tabular}{lcccccccc}
\hline Statistical Measures & Tata & Maruti & Mahindra & Hero & Bajaj & Ashok & TVS & Eicher \\
\hline Mean-PBDIT ratio & 7.50 & 14.50 & 14.27 & 14.59 & 23.37 & 9.43 & 7.39 & 29.20 \\
Rank-PBDIT $\left(\mathrm{R}_{1}\right)$ & 8 & 4 & 5 & 3 & 2 & 6 & 7 & 1 \\
SD & 3.38 & 3.11 & 1.44 & 2.88 & 1.58 & 3.09 & 0.98 & 5.89 \\
CV-PBDIT ratio & 0.45 & 0.21 & 0.10 & 0.19 & 0.06 & 0.32 & 0.13 & 0.20 \\
Rank- CV $\left(\mathrm{R}_{2}\right)$ & 8 & 6 & 2 & 4 & 1 & 7 & 3 & 5 \\
$\mathrm{D}^{2}=\left(\mathrm{R}_{1}-\mathrm{R}_{2}\right)^{2}$ & 0 & 4 & 9 & 1 & 1 & 1 & 16 \\
\hline
\end{tabular}

Source: Calculation based on ratios given in appendix 1.

$\mathrm{r}_{\mathrm{s}}=1-\frac{6 \sum(D * D)}{n(n * n-1)}=1-\frac{6 \sum(48)}{8(8 * 8-1)}=0.43$

Table 2 states the ranking of PBIDIT ratio and variability of PBDIT ratio and reveals moderate relational correlation $\left(\mathrm{r}_{\mathrm{s}}=0.43\right)$ between them. This refers that there is no significant relationship between the level of manufacturing efficiency (PBIDT ratio) and variability in manufacturing efficiency for the period 2011 to 2020. As per the explanation of the interpretation of the Coefficient of Variation (CV), the variability of all PBDIT ratios of all leading Indian automobile companies is normal or insignificantly different as the $\mathrm{CV}$ is lesser than 0.30 or closer to 0.3 except Tata Motors Ltd. This indicates some other factors other than manufacturing efficiency affect the PBIDT ratio variability. Probably, the level of production or level of activities affects the PBDIT ratio due to the maximum allocation of fixed costs to the production units.

\subsection{PBIT (Profit before Interest, and Tax) disparity and variability}

PBIT (Profit before Interest, and Tax) is the absolute amount obtained deducting all the direct and indirect manufacturing cost and depreciation from the revenue, or excess of revenue over all direct manufacturing cost, indirect manufacturing cost, and depreciation is called PBIT.

PBIT Ratio $=\frac{P B I T}{\text { Revenue }} 100$;

Where, PBIT $=$ Revenue - Direct and Indirect manufacturing cost - Depreciation,

The higher PBIT ratio reflects the manufacturing efficiency, cost control over the direct, and indirect cost of manufacturing and efficient utilization of the depreciable assets of the business organization.

Table 3

ANOVA of PBIT ratio of Indian leading automobile companies

\begin{tabular}{lcccccc}
\hline \multicolumn{1}{c}{ Source of Variation } & $S S$ & $d f$ & $M S$ & $F$ & $P$-value & F crit \\
\hline Between Groups & 5015 & 7 & 716.428 & 68.15273 & $3.23 \mathrm{E}-29$ \\
Within Groups & 756.87 & 72 & 10.5121 & & \\
\hline Total & 5771.9 & 79 & & & & \\
\hline Source: Calculation based on ratios given in appendix 2. & & & &
\end{tabular}

Based on the results of Table 3, hypothesis $\mathrm{H} 02$ is rejected as the calculated value of the F ratio (68.15273) is more than the critical value of the $\mathrm{F}$ ratio (2.139656). Hence, there is a significant difference among the average PBIT profitability of the leading Indian automobile companies. The comparative average PBIT ratio and variability explain the average PBIT and its comparative variability trend. Table 4 states the ranking of PBIT ratio and variability of PBIT ratio and reveals moderate relational correlation $\left(r_{s}=0.49\right)$ between them. This refers that there is no significant relationship between the level of manufacturing efficiency and efficient utilization of depreciable assets (PBIDT ratio) and variability in manufacturing efficiency and efficient utilization of depreciable assets for the period 2011 to 2020. As per the explanation of the interpretation of the Coefficient of Variation (CV), the variability of all PBIT ratios of all leading Indian automobile companies is normal or insignificantly different as the CV is lesser than 0.30 or closer to 0.3 except Tata Motors Ltd. and Ashok Leyland.

\section{Table 4}

Relational Co-variability of average PBIT ratio and variability of PBIT ratio of leading Indian automobile companies (2011 to 2020)

\begin{tabular}{lcccccccc}
\hline Statistical Measures & Tata & Maruti & Mahindra & Hero & Bajaj & Ashok & TVS & Eicher \\
\hline Mean-PBIT ratio & 2.23 & 10.48 & 11.53 & 13.64 & 22.36 & 6.60 & 5.36 & 26.88 \\
Rank-PBIT $\left(\mathrm{R}_{1}\right)$ & 8 & 5 & 4 & 3 & 2 & 6 & 7 \\
SD & 4.83 & 2.96 & 1.34 & 2.01 & 1.41 & 3.62 & 0.66 & 5.54 \\
CV-PBIT ratio & 2.17 & 0.28 & 0.12 & 0.15 & 0.06 & 0.55 & 0.12 & 0.21 \\
Rank- CV $\left(R_{2}\right)$ & 8 & 6 & 2.5 & 4 & 1 & 7 & 2.5 & 5 \\
$\mathrm{D}^{2}=\left(\mathrm{R}_{1}-\mathrm{R}_{2}\right)^{2}$ & 0 & 1 & 2.25 & 1 & 1 & 1 & 20.25 & 16 \\
\hline & & & & & & & \multicolumn{2}{c}{ D2 $=42.50$} \\
\hline
\end{tabular}


This indicates some other factors other than manufacturing efficiency affect the PBIT ratio variability and depreciation ratio in all automobile companies are the same. The relational correlation between PBIDT ratio and CV of PBDIT ratio $\left(\mathrm{r}_{\mathrm{s}}=0.43\right)$ and PBIT ratio and CV of PBIT $\left(r_{\mathrm{s}}=0.490\right.$ is almost similar and refers to the similar efficient utilization of depreciable assets by th3 leading Indian automobile companies.

$\mathrm{r}_{\mathrm{s}}=1-\frac{6 \sum(D * D)}{n(n * n-1)}=1-\frac{6 \sum(42.50)}{8(8 * 8-1)}=0.49$

\subsection{PBT (Profit before Tax) disparity and variability}

PBT (Profit before Tax) is the absolute amount is obtained deducting all the direct and indirect manufacturing cost, depreciation and interest from the revenue, or excess of revenue over the all direct manufacturing cost, indirect manufacturing cost, depreciation and interest is called PBT.

PBT Ratio $=\frac{P B T}{\text { Revenue }} 100$,

where, PBT= Revenue - Direct and Indirect manufacturing cost - Depreciation- Interest,

The higher PBT ratio reflects the manufacturing efficiency, cost control over the direct and indirect cost of manufacturing, efficient utilization of the depreciable assets, employment of low-cost capital, or employment of internal funds by the business organization.

\section{Table 5}

ANOVA of PBT ratio of Indian leading automobile companies

\begin{tabular}{lrrrrr}
\multicolumn{1}{c}{ Source of Variation } & SS & df & MS & F & P crit \\
\hline Between Groups & 6423 & & 7 & 917.5477 & 70.34289 \\
Within Groups & 939 & 72 & 13.04393 & \\
\hline Total & 7362 & 79 & & \\
\hline
\end{tabular}

Source: Calculation based on ratios given in appendix 3.

Based on the results of Table 5, hypothesis $\mathrm{H}_{0} 3$ is rejected as the calculated value of the $\mathrm{F}$ ratio (70.34289) is more than the critical value of the $\mathrm{F}$ ratio (2.139656). Hence, there is a significant difference among the average PBT profitability of the leading Indian automobile companies. The comparative average PBT ratio and variability explain the average PBT and its comparative variability trend.

\section{Table 6}

Relational Co-variability of average PBT ratio and variability of PBT ratio of leading Indian automobile companies (2011 to 2020)

\begin{tabular}{lcccccccc}
\hline Statistical Measures & Tata & Maruti & Mahindra & Hero & Bajaj & Ashok & TVS & Eicher \\
\hline Mean-PBT ratio & -2.57 & 10.23 & 11.12 & 13.73 & 22.65 & 4.93 & 4.66 & 26.45 \\
Rank-PBT $\left(\mathrm{R}_{1}\right)$ & 8 & 5 & 4 & 3 & 2 & 6 & 7 & 1 \\
SD & 6.64 & 2.98 & 2.02 & 2.22 & 2.18 & 3.08 & 1.06 & 5.21 \\
CV-PBT ratio & -2.58 & 0.29 & 0.18 & 0.16 & 0.10 & 0.62 & 0.23 & 0.20 \\
Rank- CV $\left(\mathrm{R}_{2}\right)$ & 8 & 6 & 3 & 2 & 1 & 7 & 5 \\
$\mathrm{D}^{2}=\left(\mathrm{R}_{1}-\mathrm{R}_{2}\right)^{2}$ & 0 & 1 & 1 & 1 & 1 & 1 & 4 \\
\hline
\end{tabular}

Source: Calculation based on ratios given in appendix 3 .

$\mathrm{r}_{\mathrm{s}}=1-\frac{6 \sum(D * D)}{n(n * n-1)}=1-\frac{6 \sum(18)}{8(8 * 8-1)}=0.79$

Table 6 states the ranking of PBT ratio and variability of PBT ratio and reveals a high degree relational correlation $\left(\mathrm{r}_{\mathrm{s}}=0.79\right)$ between them. This refers to a significant relationship between the level of manufacturing efficiency, efficient utilization of depreciable assets, cost of external funds and variability in manufacturing efficiency, efficient utilization of depreciable assets, and cost of external capital for the period 2011 to 2020. As per the explanation of the interpretation of the Coefficient of Variation (CV), the variability of all PBT ratios of all leading Indian automobile companies is normal or insignificantly different as the CV is lesser than 0.30 or closer to 0.3 except Tata Motors Ltd. and Ashok Leyland. This reveals that the PBT of all companies is normally variable except Tata Motors Ltd. and Ashok Leyland. The high degree relational correlation between the PBT ratio and variability of PBT ratio indicates that the PBT profitability governs the interest factor positively. In other words, it can be said that the outcomes of utilizing their external funds are similar to earning profit.

\subsection{PAT (Profit after Tax) disparity and variability}

PAT (Profit After Tax) is the absolute amount obtained deducting all the direct and indirect manufacturing cost, depreciation and interest, and taxes from the revenue, or excess of revenue overall direct manufacturing cost, indirect manufacturing cost, depreciation, interest, and taxes is called PAT. 
1460

PAT Ratio $=\frac{P A T}{\text { Revenue }} 100$,

where, PAT $=$ Revenue - Direct and Indirect manufacturing cost - Depreciation- Interest - Tax,

The higher PAT ratio reflects the manufacturing efficiency, cost control over the direct and indirect cost of manufacturing, efficient utilization of the depreciable assets, employment of low-cost capital or employment of internal funds, and management of taxes by the business organization.

Table 7

ANOVA of PBT ratio of Indian leading automobile companies

\begin{tabular}{|c|c|c|c|c|c|c|}
\hline Source of Variation & $S S$ & $d f$ & $M S$ & $F$ & $P$-value & $F$ crit \\
\hline Between Groups & 3485.258 & 7 & 497.894 & 52.72422 & $7.84 \mathrm{E}-26$ & 2.139656 \\
\hline Within Groups & 679.9222 & 72 & 9.443364 & & & \\
\hline Total & 4165.18 & 79 & & & & \\
\hline
\end{tabular}

Source: Calculation based on ratios given in appendix 4

Based on the results of Table 7, hypothesis H04 is rejected as the calculated value of the F ratio (52.72422) is more than the critical value of the F ratio (2.139656). Hence, there is a significant difference among the average PAT profitability of the leading Indian automobile companies. The comparative average PAT ratio and variability explain the average PAT and its comparative variability trend.

\section{Table 8}

Relational Co-variability of average PAT ratio and variability of PAT ratio of leading Indian automobile companies (2011 to 2020)

\begin{tabular}{|c|c|c|c|c|c|c|c|c|}
\hline Statistical Measures & Tata & Maruti & Mahindra & Hero & Bajaj & Ashok & TVS & Eicher \\
\hline Mean-PAT ratio & -2.63 & 7.61 & 8.34 & 10.28 & 16.37 & 3.91 & 3.56 & 19.15 \\
\hline Rank-PAT $\left(\mathrm{R}_{1}\right)$ & 8 & 5 & 4 & 3 & 2 & 6 & 7 & 1 \\
\hline SD & 6.98 & 1.99 & 2.13 & 1.42 & 1.93 & 2.32 & 0.85 & 2.54 \\
\hline CV-PAT ratio & -2.65 & 0.26 & 0.26 & 0.14 & 0.12 & 0.59 & 0.24 & 0.13 \\
\hline Rank- CV $\left(\mathrm{R}_{2}\right)$ & 8 & 5.5 & 5.5 & 3 & 1 & 7 & 4 & 2 \\
\hline $\mathrm{D}^{2}=\left(\mathrm{R}_{1}-\mathrm{R}_{2}\right)^{2}$ & 0 & 0.25 & 2.25 & 0 & 1 & 1 & 9 & 1 \\
\hline
\end{tabular}

Source: Calculation based on ratios given in appendix 4.

$\mathrm{r}_{\mathrm{s}}=1-\frac{6 \sum(D * D)}{n(n * n-1)}=1-\frac{6 \sum(14.50)}{8(8 * 8-1)}=0.83$

Table 8 states the ranking of PAT ratio and variability of PAT ratio and reveals a high degree relational correlation $\left(\mathrm{r}_{\mathrm{s}}=0.83\right)$ between them. This refers that there is a significant relationship between the level of manufacturing efficiency, efficient utilization of depreciable assets, cost of external funds, taxes and variability in manufacturing efficiency, efficient utilization of depreciable assets, and cost of external capital, taxes for the period 2011 to 2020. As per the explanation of the interpretation of the Coefficient of Variation (CV), the variability of all PAT ratios of all leading Indian automobile companies is normal or insignificantly different as the CV is lesser than 0.30 or closer to 0.3 except Tata Motors Ltd. and Ashok Leyland. This reveals that the PAT of all companies is normally variable except Tata Motors Ltd. and Ashok Leyland. The high degree relational correlation between the PBT ratio and variability of PBT ratio indicates that the PAT profitability associates interest factor positively. In other words, it can be said that imposing the tax in leading Indian automobile companies is similar.

\section{Discussion}

Based on past studies and available information about financial performance and growth and development, it can be said that the Indian automobile sector is one of the most booming sectors in the economy. But, the earning capacity of the Leading Indian automobile companies is significantly different. Possibly, the reason for the difference in profitability is the level of activities, the composition of products, and demand of the products, and availability of similar international products in the market. The results of ANOVA interpret significant differences among the PBDIT, PBIT, PBT, and PAT of the leading Indian automobile sector companies. The moderate relational relationship between PBDIT ratio and variability of PBDIT and PBIT ratio and variability of PBIT ratio indicates no significant relationship between the profitability and variability of the profitability. It is not necessary that if the company is profitable so it would be necessarily a profitability variable. But, a high degree relational relationship between PBT ratio and variability of PBT and PAT ratio and variability of PAT ratio indicates a significant relationship between the profitability and variability of the profitability. This refers to the circulatory relationship between the level of profitability and variability of profitability after considering the interest and tax factors in the automobile companies of India. 


\section{Conclusion}

Indian automobile sector companies contribute Indian economy and enhance the GDP growth and displace the advanced countries at the international level. The profitability of the Indian automobile sector companies is significantly different. There is a circulative relationship between the profitability and variability of the profitability after considering the interest and taxes. On one hand, it refers that companies are utilizing their funds efficiently to enhance their income and, on another hand, it indicates the positivity between the number of external funds, taxable profits, and absolute of interest and taxes. The performance of few leading automobile companies is negative during the period of study i.e., 2011 to 2020 and negative leads to the high variability in profitability in expectation to recover the losses and attain the positivity of profits. The negatively performing companies have to focus on financial and non-financial factors to improve their profitability. Possible reduction in all direct and indirect costs, optimum cost of capital, or low cost of capital structure can be considered to avoid excessive burden against the profits of the negatively performing automobile sector companies a financial factor. Salable products, a higher level of activities, advanced products, and appropriate marketing strategy can help enhance the profitability and profits, overall.

\section{References}

Ali, A. (2020). Financial performance and size determinants: growth trend and similarity analysis of Indian pharmaceutical industry. Humanities \& Social Sciences Reviews, 8(4), 547-560.

Arumugam, D., Kumar, A. M., \& Preetha, R. (2016). Factors Determining Profitability in Indian Automobile Industry. Indian Journal of Commerce and Management Studies, 7(2), 64-69.

Ashraf, C. K. (2012). The relationship between working capital efficiency and profitability. Journal of Accounting and Management, 2(3), 21-45.

Attari, M. A., \& Raza, K. (2012). The optimal relationship of cash conversion cycle with firm size and profitability. International Journal of Academic Research in Business and Social Sciences, 2(4), 189-203.

Gandhi, K. (2017). Profitability Analysis of Select Automobile Companies in India-With Special Reference to Tata Motors and Mahindra and Mahindra. SJCC Management Research Review, 7(2), 82-90.

Gopalakrishnan, C. (2014). Profitability Trend in BSE Listed Automobile Sector in India. RVS Journal of Management, 6(2), 85-95.

Hassan, M., \& Shrivastava, S. K. (2019). Working Capital Management and Its Impact on the Profitability of Tata Motors. In Proceedings of 10th International Conference on Digital Strategies for Organizational Success.

Hiran, S. (2016). Financial Performance Analysis of Indian Companies Belongs to Automobile Industry with Special Reference to Liquidity \& Leverage. International Journal of Multidisciplinary and Current Research, 4, 39-51.

Jaisinghani, D., \& Tandon, D. (2016). R \& D, Profit persistence impact on profitability of the Indian automobile sector. APEA, $1-43$.

Jamali, A. H., \& Asadi, A. (2012). Management efficiency and profitability in Indian automobile industry: From theory to practice. Indian Journal of Science and Technology, 5(5), 2779-2781.

Kaur, N., \& Kaur, J. (2016). Determinants of profitability of automobile industry in India. Journal of Commerce \& Accounting Research, 5(3), 32-39.

Kumar, N., \& Choudhary, P. (2019). A Study of the Structure, Conduct and Performance of Indian Automobile Industry. Empirical Economic Letters, 18(9), 303-310.

Kumar, N., \& Kaur, K. (2016). Firm size and profitability in Indian automobile industry: An analysis. Pacific Business Review International, 8(7), 69-78.

Paliwal, R., \& Chouhan, V. (2017). Relationship between Liquidity and Profitability in Indian Automobile Industry. International Journal of Science and Research (IJSR ISSN (Online): 2319-7064.

Ranjithkumar, M.S. \& Eahambaram, C. (2018). A study on profitability analysis of Indian selected automobile industry in India. International Journal for Research in Engineering Application \& Management, 2(7), 412-416.

Shajar, S. N. (2017). Relationship between Working Capital Management and Profitability of Automobile Companies in India: A Paradigm Shift towards Economic Strengthening. International Journal of Trade, Economics and Finance, 8(4), 210-216.

Simlai, D., \& Guha, M. (2019). Financial stability, profitability and growth analysis: a study on select Indian automobile companies. Journal of Commerce \& Accounting Research, 8(1),21-34.

Singh, G., Kashyap, S., Tomar, K. S., \& Garg, V. (2020). A Study of Business Performance Management in Special Reference to Automobile Industry. In Data Management, Analytics and Innovation (pp. 69-92). Springer, Singapore.

Suresh, S., \& Sengottaiyan, A. (2015). Does Capital Structure Decision Affects Profitability? A Study of Selected Automobile Companies in India. International Journal of Research in Social Sciences, 5(4), 113-123.

Swalih, M., Adarsh, K., \& Sulphey, M. (2021). A study on the financial soundness of Indian automobile industries using Altman Z-Score. Accounting, 7(2), 295-298.

Tripathi, S., \& Talukder, B. (2020). Supply chain performance and profitability in Indian automobile industry: Evidence of segmental difference. Global Business Review, 1-22. DOI: 10.1177/0972150919898302 
1462

Tripathi, V., \& Rao, K. B. (2016). Progress Card of the Indian Automobile Industry. IUP Journal of Business Strategy, 13(3), 48-61.

\section{Appendices}

\section{Appendix 1}

$\underline{\text { Profit Before Depreciation, Interest and Tax( PBDIT) of Indian automobile companies }}$

\begin{tabular}{|c|c|c|c|c|c|c|c|c|}
\hline Years & Tata & Maruti & Mahindra & Hero & Bajaj & Ashok & TVS & Eicher \\
\hline 2020 & 1.66 & 14.18 & 16.41 & 16.42 & 22.82 & 7.42 & 8.39 & 31.05 \\
\hline 2019 & 10.82 & 15.76 & 15.53 & 16.7 & 21.92 & 11.17 & 7.91 & 35.24 \\
\hline 2018 & 8.27 & 17.68 & 14.91 & 18.01 & 24.36 & 11.98 & 8.42 & 35.56 \\
\hline 2017 & 5.84 & 18.59 & 13.3 & 18.09 & 25.93 & 11.61 & 8.49 & 34.57 \\
\hline 2016 & 10.15 & 17.98 & 13.38 & 16.91 & 25.92 & 12.52 & 8.22 & 32.19 \\
\hline 2015 & 1.77 & 15.09 & 12.89 & 12.66 & 21.74 & 8.48 & 6.3 & 30.69 \\
\hline 2014 & 8.52 & 13.54 & 13.42 & 11.39 & 23.88 & 2.34 & 6.38 & 28.03 \\
\hline 2013 & 8.48 & 11.56 & 13 & 10.69 & 22.15 & 7.52 & 6.12 & 23.13 \\
\hline 2012 & 8.74 & 9.38 & 13.29 & 12.23 & 22.16 & 10.09 & 6.89 & 18.22 \\
\hline 2011 & 10.8 & 11.32 & 16.57 & 12.88 & 22.85 & 11.25 & 6.8 & 23.36 \\
\hline
\end{tabular}

Source: Author's own calculation based on data contained in the financial statements of the concerned Indian automobile companies.

\section{Appendix 2}

Profit Before Interest and Tax ( PBIT) of Indian automobile companies

\begin{tabular}{|c|c|c|c|c|c|c|c|c|}
\hline Years & Tata & Maruti & Mahindra & Hero & Bajaj & Ashok & TVS & Eicher \\
\hline 2020 & -6.01 & 9.51 & 11.52 & 13.58 & 22 & 3.59 & 5.41 & 26.89 \\
\hline 2019 & 6.35 & 12.25 & 12.06 & 14.91 & 21.04 & 9.03 & 5.71 & 32.19 \\
\hline 2018 & 2.99 & 14.22 & 11.87 & 16.29 & 23.11 & 9.71 & 6.18 & 33.08 \\
\hline 2017 & -1 & 14.77 & 9.83 & 16.36 & 24.51 & 9.04 & 6.11 & 32.39 \\
\hline 2016 & 4.71 & 13.07 & 10.76 & 15.37 & 24.56 & 9.95 & 6.1 & 29.98 \\
\hline 2015 & -5.39 & 10.15 & 10.39 & 12.66 & 20.5 & 5.41 & 4.78 & 28.55 \\
\hline 2014 & 2.48 & 8.77 & 11.29 & 11.39 & 22.99 & -1.44 & 4.73 & 26.38 \\
\hline 2013 & 4.42 & 7.29 & 11.24 & 10.69 & 21.33 & 4.47 & 4.28 & 21.34 \\
\hline 2012 & 5.79 & 6.18 & 11.49 & 12.23 & 21.41 & 7.34 & 5.24 & 16.58 \\
\hline 2011 & 7.91 & 8.55 & 14.81 & 12.88 & 22.1 & 8.86 & 5.09 & 21.42 \\
\hline
\end{tabular}

Source: Author's own calculation based on data contained in the financial statements of the concerned Indian automobile companies.

\section{Appendix 3}

$\underline{\text { Profit Before Tax (PBT) of Indian automobile companies }}$

\begin{tabular}{|c|c|c|c|c|c|c|c|c|}
\hline Years & Tata & Maruti & Mahindra & Hero & Bajaj & Ashok & TVS & Eicher \\
\hline 2020 & -16.22 & 9.34 & 6.85 & 15.86 & 21.99 & 2.07 & 4.59 & 26.77 \\
\hline 2019 & 3.46 & 12.16 & 11.79 & 14.89 & 22.15 & 8.59 & 5.27 & 31.98 \\
\hline 2018 & -1.60 & 13.79 & 12.53 & 16.27 & 22.97 & 9.05 & 5.80 & 29.56 \\
\hline 2017 & -5.31 & 14.64 & 10.72 & 16.34 & 24.51 & 6.60 & 5.75 & 32.35 \\
\hline 2016 & 0.36 & 12.93 & 10.48 & 15.36 & 24.56 & 4.36 & 5.66 & 29.95 \\
\hline 2015 & -10.95 & 9.74 & 10.70 & 12.06 & 18.90 & 3.26 & 4.51 & 28.51 \\
\hline 2014 & -2.99 & 8.37 & 10.78 & 11.34 & 22.98 & -0.91 & 4.37 & 26.32 \\
\hline 2013 & 0.39 & 6.86 & 10.99 & 10.64 & 21.33 & 3.77 & 2.30 & 21.33 \\
\hline 2012 & 2.46 & 6.03 & 11.32 & 12.14 & 20.61 & 5.37 & 4.44 & 16.56 \\
\hline 2011 & 4.66 & 8.48 & 15.00 & 12.39 & 26.51 & 7.17 & 3.94 & 21.12 \\
\hline
\end{tabular}

Source: Author's own calculation based on data contained in the financial statements of the concerned Indian automobile companies.

\section{Appendix 4}

Profit After Tax (PBT) of Indian automobile companies

\begin{tabular}{|c|c|c|c|c|c|c|c|c|}
\hline Years & Tata & Maruti & Mahindra & Hero & Bajaj & Ashok & TVS & Eicher \\
\hline 2020 & -16.59 & 7.47 & 2.92 & 12.59 & 17.04 & 1.37 & 3.6 & 20.97 \\
\hline 2019 & 2.91 & 8.71 & 8.94 & 10.05 & 15.45 & 6.82 & 3.68 & 20.97 \\
\hline 2018 & -1.75 & 9.68 & 8.94 & 11.47 & 16.16 & 6.51 & 4.37 & 19.12 \\
\hline 2017 & -5.48 & 10.8 & 8.27 & 11.84 & 17.58 & 6.07 & 4.59 & 22.16 \\
\hline 2016 & -0.14 & 9.32 & 7.83 & 10.95 & 17.39 & 2.05 & 4.4 & 21.16 \\
\hline 2015 & -13.05 & 7.42 & 8.52 & 8.64 & 13.01 & 2.46 & 3.44 & 20 \\
\hline 2014 & 0.97 & 6.36 & 9.27 & 8.34 & 16.09 & 0.29 & 3.28 & 18.43 \\
\hline 2013 & 0.67 & 5.48 & 8.29 & 8.91 & 15.21 & 3.47 & 1.64 & 16.36 \\
\hline 2012 & 2.28 & 4.59 & 9.03 & 10.08 & 15.38 & 4.4 & 3.49 & 13.79 \\
\hline 2011 & 3.84 & 6.24 & 11.34 & 9.93 & 20.36 & 5.64 & 3.09 & 18.54 \\
\hline
\end{tabular}

Source: Author's own calculation based on data contained in the financial statements of the concerned Indian automobile companies.

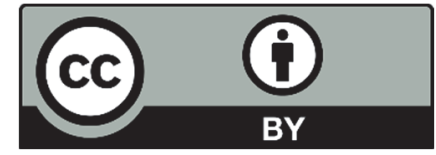

(C) 2021 by the authors; licensee Growing Science, Canada. This is an open access article distributed under the terms and conditions of the Creative Commons Attribution (CC-BY) license (http://creativecommons.org/licenses/by/4.0/). 